\title{
Hubungan Faktor Risiko, Status Instabilitas Mikrosatelit, dan Ekspresi P53 dengan Karsinogenesis Adenokarsinoma Kolorektal pada Orang Indonesia
}

\author{
Kiki Lukman, ${ }^{1}$ Laely Yuniasari, ${ }^{1}$ Bethy S. Hernowo ${ }^{2}$ \\ ${ }^{1}$ Departemen Bedah, ${ }^{2}$ Departemen Patologi Anatomi Fakultas Kedokteran Universitas Padjadjaran- \\ Rumah Sakit Dr. Hasan Sadikin Bandung
}

\begin{abstract}
Abstrak
Berbeda dengan berbagai negara lain, karakteristik molekuler adenokarsinoma kolorektal (AKK) pada orang Indonesia di dalam kelompok usia $\leq 40$ tahun memiliki kesamaan dengan kelompok usia $>40$ tahun, dan keduanya berada pada jalur karsinogenesis sporadik. Untuk mengetahui hubungan karakteristik molekuler dengan berbagai faktor risiko $\mathrm{AKK}$, dilakukan penelitian potong lintang yang mempelajari hubungan berbagai faktor risiko, status instabilitas mikrosatelit (IM), dan ekspresi P53 (instabilitas kromosom=IK) pada 39 penderita AKK yang memenuhi kriteria inklusi di Rumah Sakit Dr. Hasan Sadikin Bandung dalam periode Maret 2009-Maret 2010. Diperoleh masing-masing 21 dan 18 penderita AKK laki-laki dan perempuan, serta 17 dan 22 penderita berusia $>40$ dan $\leq 40$ tahun. Dilakukan pemeriksaan imunohistokimia ekspresi gen $M L H 1, M S H 2$, dan $p 53$ untuk menentukan status IM dan IK. Hasilnya adalah penderita AKK $\leq 40$ tahun menunjukkan 4 IM tinggi, 1 IM rendah, dan 17 IM negatif, serta 10 status P53 positif dan 12 P53 negatif. Penderita AKK $>40$ tahun menunjukkan 4 IM rendah, dan 13 IM negatif, yang disertai oleh 11 status P53 positif dan 6 status P53 negatif. Pada kedua kelompok tersebut tidak didapatkan perbedaan yang bermakna $(\mathrm{p}>0,05)$ dalam pola hubungan berbagai faktor risiko AKK dengan karakteristik molekulernya. Pola diet tinggi lemak dan protein, rendah serat, overweight, merokok, dan aktivitas fisik rendah ditemukan sebagai faktor risiko yang berperan pada kedua kelompok tersebut. Simpulan, mayoritas penderita AKK pada orang Indonesia memiliki klasifikasi molekuler berupa status IK tinggi dan status IM rendah, serta berhubungan dengan faktor risiko diet tinggi lemak dan protein, rendah serat, overweight, merokok, dan aktivitas fisik rendah. [MKB. 2012;44(4):245-52]
\end{abstract}

Kata kunci: Ekspresi P53, faktor risiko, instabilitas mikro-satelit, karsinogenesis adenokarsinoma kolorektal

\section{The Association of Risk Factors, Microsatellite Instability, and P53 Expression in the Carcinogenesis of Colorectal Adenocarcinoma among Indonesian}

\begin{abstract}
Different from developed countries, molecular characteristic of colorectal adenocarcinoma (CRC) among Indonesians in the age group of $\leq 40$ years old is mostly similar compared to the CRC of the age group of $>40$ years old, and both are sporadic cancers. To know the association of molecular characteristic with the risk factors of CRC, a cross sectional study was conducted to analyze the association of risk factors, microsatellite instability (MSI) and P53 expression (chromosomal Instability=CIN) status in 39 consecutive CRC patients who were eligible for this study at Dr Hasan Sadikin Hospital, from March 2009 until March 2010. They consisted of 21 male and 18 female patients. Of them, there were 17 and 22 patients with $>40$ and $\leq 40$ years of age, respectively. The immuno-histochemistry examinations for the expression of mutated MLH1, MSH2 and p53 genes were conducted to determine the CIN and MSI status. The results showed that the CRC $\leq 40$ years of age had 4 MSI high, 1 MSI low, and 17 MSI negative, associated with 10 P53 positives and 12 p53 negatives. By contrast, in the CRC $>40$ years of age the MSI was low and negative in 4 and 13 cases, respectively. They were associated with 11 and 6 of p53 positive and negative status, respectively. Between the two groups, there were no significant differences with regards to the association pattern between the risk factors and their molecular characteristics ( $p>0.05)$. Conclusions, majority of CRC patients among Indonesian show a molecular classification of high CIN and low MSI, and is associated with risk factors of high fat and protein, low fiber dietary intake, overweight, smoking, and low physical activitis. [MKB. 2012;44(4):245-52]
\end{abstract}

Key words: Carcinogenesis of colorectal carcinoma, expression of P53, microstallite instability, risk factors

Korespondensi: Kiki Lukman, dr., M.Sc., Sp.B-KBD, Departemen Ilmu Bedah Fakultas Kedokteran Universitas PadjadjaranRumah Sakit Dr. Hasan Sadikin Bandung, mobile 0811237426, e-mail klukman@yahoo.com 


\section{Pendahuluan}

Adenokarsinoma kolorektal (AKK) menduduki urutan ketiga di seluruh dunia sebagai kanker yang terbanyak dijumpai pada laki-laki, kedua pada perempuan, serta urutan keempat penyebab kematian akibat kanker. ${ }^{1}$ Estimasi World Health Organization (WHO) diperkirakan sebanyak 1,2 juta kasus baru per tahun dilaporkan di seluruh dunia dengan 608.700 kematian setiap tahun. ${ }^{2}$ Secara umum insidensi di negara maju sebesar 50,9-60,8 kasus/100.000 penduduk, sedangkan di negara berkembang 6,5-7,7 kasus/100.000 penduduk. .,3 $^{2}$ Berdasarkan laporan WHO pada tahun 2002, insidensi AKK di Indonesia sebesar 17,8/100.000 penduduk dan hal ini menunjukkan peningkatan insidensi AKK dibandingkan dengan berbagai laporan sebelumnya. ${ }^{4}$

Lebih dari 90\% kasus AKK telah didiagnosis pada usia $>55$ tahun. $^{5}$ Persentase AKK usia $<40$ tahun bervariasi mulai dari $0,4 \%$ sampai dengan 35,6\%. ${ }^{6,7}$ Persentase kelompok tersebut di negara Eropa dan Amerika Utara lebih rendah dibandingkan dengan negara Asia, yaitu berkisar antara 2\% sampai dengan $8 \%{ }^{8,9}$ Pada tahun 1995-1999 persentase AKK di Indonesia pada kelompok usia $<40$ tahun sebanyak $15-54,5 \% .^{10}$

Di negara Eropa dan Amerika, mayoritas penderita AKK $\leq 40$ tahun adalah herediter dalam bentuk hereditary non polyposis colorectal carcinoma (HNPCC) atau familial adenomatous polyposis (FAP). Jumlah polip lebih dari 100 buah ditemukan pada FAP dan kira-kira terdapat pada $1 \%$ kasus saja, sedangkan sisanya merupakan HNPCC (2-5\%). ${ }^{7}$

Secara genetik, mekanisme karsinogenesis AKK telah diketahui dalam dua bentuk yaitu jalur AKK sporadik dan herediter. ${ }^{8,11}$ Sekitar $88-94 \%$ penderita AKK di Eropa Barat dan Amerika adalah jenis sporadik, sedangkan sisanya yaitu $5-10 \%$ dalam bentuk herediter. ${ }^{8,11}$ Oleh karena itu, jika ditemukan pada usia $<40$ tahun maka tergolong dalam jenis AKK herediter. ${ }^{8}$ Walaupun persentase penderita $\mathrm{AKK} \leq 40$ tahun di Indonesia jauh lebih tinggi dibandingkan dengan di negara Eropa dan Amerika. Proporsi penderita dengan riwayat herediter sangat rendah pada seri kasus yang pernah dilaporkan. ${ }^{10}$ Pada studi pendahuluan yang penulis telah lakukan di Rumah Sakit Dr. Hasan Sadikin (RSHS), terbukti bahwa karakteristik molekuler AKK pada orang Indonesia di dalam kelompok usia $\leq 40$ tahun memiliki kesamaan dengan kelompok usia $>40$ tahun dan keduanya terdapat pada jalur karsinogenesis sporadik dengan karakteristik molekuler yaitu tingginya ekspresi P53 yang berhubungan terbalik dengan rendahnya status IM (data belum dipublikasikan).

Pada jalur sporadik, etiologi AKK belum jelas benar. Berdasarkan basis bukti yang ada, berbagai faktor risiko AKK telah diketahui, yaitu diet tinggi lemak dan protein, rendah serat, penderita adenoma kolorektal, penyakit Crohn dan kolitis ulserativa yang telah diderita lebih dari 10 tahun, alkohol, obesitas, merokok, serta aktivitas fisik rendah. ${ }^{6}$ Pada jalur herediter, mutasi gen yang diperoleh dari orangtua penderita menyebabkan kanker setelah interaksi dengan faktor lingkungan yang juga menyebabkan rangkaian mutasi gen berikutnya. ${ }^{11}$

Hubungan antara klasifikasi molekuler dan faktor risiko AKK dilakukan dengan pemeriksaan status IM melalui ekspresi mutasi gen $M L H 1$, MSH2, serta ekspresi P53 (status instabilitas kromosom=IK), dan juga meneliti hubungannya dengan berbagai faktor risiko pada penderita AKK orang Indonesia. Sesudah itu, dilakukan perbandingan pola hubungan tersebut antara penderita $A K K \leq 40$ tahun dan $>40$ tahun. Dengan demikian, diharapkan dapat memberi penjelasan lebih lanjut tentang karakteristik patobiologi molekuler pada penderita AKK yang berusia $\leq 40$ tahun pada orang Indonesia dan mengetahui berbagai faktor risiko yang mungkin berperan dalam karsinogenesis, bermanfaat dalam aplikasi pengelolaan, khususnya skrining, surveilans, dan pemilihan terapi adjuvan, serta pencegahannya melalui pengenalan faktor risiko pada kelompok tersebut.

\section{Metode}

Penelitian ini telah dilakukan di Divisi Ilmu Bedah Digestif, Departemen Ilmu Bedah, dan Departemen Patologi Anatomi, Fakultas Kedokteran Unpad/RSHS Bandung dari bulan Maret 2009-Maret 2010.

Subjek penelitian adalah penderita AKK yang merupakan orang Indonesia asli dan berdomisili di Indonesia. Kriteria inklusi penelitian ini yaitu penderita AKK dan baru didiagnosis pertama kali, menjalani operasi di RSHS Bandung, dan bangsa Indonesia asli dengan mengisi daftar silsilah 3 generasi. Penderita tersebut atau keluarganya menyatakan tidak berkeberatan diwawancarai dan spesimen dipakai sebagai bahan penelitian dengan menandatangani persetujuan (informed consent).

Kriteria eksklusi yaitu penderita AKK dengan riwayat FAP, yang menjalani radioterapi, dan/ atau kemoterapi preoperatif.

Penderita yang memenuhi kriteria inklusi dan tidak termasuk kriteria eksklusi yang diwawancara dengan mempergunakan kuesioner yang berisi faktor-faktor risiko AKK, yaitu riwayat adenoma/ karsinoma, riwayat inflammatory bowel diseases 
(IBD), riwayat kolesistektomi, diet tinggi lemak serta protein, rendah serat, alkohol, obesitas, merokok, dan aktivitas fisik yang rendah. Setelah dilakukan penetapan stadium menurut status tumor primer, nodus limfatikus, dan metastasis, pada penderita dilakukan terapi bedah definitif. Spesimen tumor yang diambil pada saat terapi bedah ditetapkan jenis histopatologi, derajat diferensiasi, serta pemeriksaan imunohistokimia pada setiap spesimen. Penentuan status IM dan IK ditetapkan pada setiap preparat, selanjutnya dianalisis hubungan asosiatif berbagai faktor risiko AKK, status IM dan IK, baik pada penderita AKK $\leq 40$ tahun, maupun penderita AKK $>40$ tahun. Uji statistik chi-kuadrat dilakukan untuk menilai perbedaan proporsi keduanya. Seluruh analisis statistik dilakukan dengan menggunakan program statistical package for the social sciences (SPSS) versi 16.0. Berdasarkan penghitungan jumlah sampel untuk perbedaan proporsi dua kelompok, dengan tingkat kemaknaan $(\alpha)=0,05$, dan kekuatan penelitian (power test) 80\%, serta proporsi standar untuk ekspresi P53 masingmasing kelompok 0,85 dan 0,15 , maka diperoleh jumlah sampel minimal 29 orang.

Instabilitas mikrosatelit ditentukan dengan pemeriksaan imunohistokimia terhadap hMLH1 dan hMSH2 dengan antibodi rabbit polyclonal dari Santa Cruz Biotechnology. Pulasan terhadap protein MMR dilakukan dengan anti-MLH1 (N20, Santa Cruz, Biotech. Inc.), dan anti-MSH2 (3A2B8C, Santa Cruz, Biotech. Inc.). Selain mutasi pada gen $p 53$ dilakukan pula pemeriksaan imunohistokimia dengan menggunakan metode kompleks avidin-biotin-peroksidase dan rabbit monoclonal antibody ( DO-7, Dako, Carpinteria, CA, USA).

\section{Hasil}

Subjek penelitian ini adalah 39 penderita AKK yang terdiri atas 21 orang laki-laki dan 18 orang perempuan. Penderita AKK dengan usia $\leq 40$ tahun diperoleh 22 orang dan usia $>40$ tahun sebanyak 17 orang.

Perbandingan lokasi tumor dan histopatologi tumor, serta riwayat adenoma/karsinoma, IBD, kolesistektomi antara penderita AKK $\leq 40$ tahun dan $>40$ tahun, hasil analisis uji chi-kuadrat pada derajat kepercayaan 95\% menunjukkan tidak terdapat perbedaan bermakna untuk lokasi tumor, histopatologi tumor, riwayat adenoma/karsinoma, riwayat $\mathrm{IBD}$, dan riwayat kolesistektom antara kedua kelompok tersebut dengan nilai $\mathrm{p}>0,05$ (Tabel 1).

Tabel 1 Hubungan Lokasi dan Histopatologi Tumor, serta Faktor Risiko Kondisi Biologik Penderita Dibandingkan Penderita AKK $\leq 40$ Tahun dengan $>40$ Tahun

\begin{tabular}{|c|c|c|c|c|}
\hline Variabel & $\begin{array}{c}\leq 40 \text { Tahun } \\
\mathbf{n}=22\end{array}$ & $\begin{array}{c}>40 \text { Tahun } \\
\mathrm{n}=17\end{array}$ & $\mathbf{p}$ & RP (95\%IK) \\
\hline Lokasi tumor & & & 0,671 & - \\
\hline Kolon kanan & 2 & 1 & & \\
\hline Kolon kiri & 1 & 2 & & \\
\hline Rektum & 19 & 14 & & \\
\hline Histopatologi tumor & & & 0,472 & - \\
\hline Diferensiasi baik & 14 & 9 & & \\
\hline Diferensiasi sedang & 3 & 6 & & \\
\hline Difertensiasi buruk & 2 & 1 & & \\
\hline Mucinous adenocarcinoma & 2 & 1 & & \\
\hline Signet ring cell & 1 & 0 & & \\
\hline Riwayat ademoma/karsinoma & & & 0,625 & $1,07(0,49-2,33)$ \\
\hline $\mathrm{Ya}$ & 4 & 2 & & \\
\hline Tidak & 18 & 15 & & \\
\hline Riwayat IBD & & & 0,625 & $1,07(0,49-2,33)$ \\
\hline Ya & 3 & 2 & & \\
\hline Tidak & 19 & 15 & & \\
\hline Riwayat cholecystectomy & & & - & - \\
\hline Ya & 0 & 0 & & \\
\hline Tidak & 22 & 17 & & \\
\hline \multicolumn{5}{|l|}{ Riwayat keluarga } \\
\hline Ya & 0 & 3 & 0,074 & $2,57(1,7-3,87)$ \\
\hline Tidak & 22 & 17 & & \\
\hline
\end{tabular}

Keterangan: $\mathrm{RP}=$ =risiko prevalens, $\mathrm{IK}=$ interval kepercayaan 
Tabel 2 Perbandingan Faktor Risiko Perilaku dan Lingkungan antara Penderita AKK $\leq 40$ Tahun dan $>40$ Tahun

\begin{tabular}{|c|c|c|c|c|}
\hline Variabel & $\begin{array}{c}\leq 40 \text { Tahun } \\
\mathrm{n}=22\end{array}$ & $\begin{array}{c}>40 \text { Tahun } \\
n=17\end{array}$ & $\mathbf{p}$ & RP (95\%IK) \\
\hline Diet lemak & & & 0,389 & $0,77(0,45-1,33)$ \\
\hline Tinggi & 14 & 13 & & \\
\hline Rendah & 8 & 4 & & \\
\hline Diet protein & & & 0,065 & $1,68(0,95-2,98)$ \\
\hline Tinggi & 13 & 5 & & \\
\hline Rendah & 9 & 12 & & \\
\hline Diet sayuran & & & 0,598 & $0,83(0,35-1,95)$ \\
\hline Rendah & 20 & 16 & & \\
\hline Tinggi & 2 & 1 & & \\
\hline Alkohol & & & 0,123 & $1,85(1,37-2,49)$ \\
\hline Positif & 2 & 0 & & \\
\hline Negatif & 20 & 17 & & \\
\hline Indeks massa tubuh & & & 0,222 & \\
\hline Underweight & 2 & 5 & & $0,98(0,50-1,90)$ \\
\hline Normal & 8 & 6 & & 1 \\
\hline Overweight & 12 & 6 & & $0,98(0,50-1,90)$ \\
\hline Merokok & & & 0,455 & $0,81(0,45-1,43)$ \\
\hline Ya & 9 & 9 & & \\
\hline Tidak & 13 & 8 & & \\
\hline Aktifitas fisik & & & 0,305 & $1,33(0,65-2,72)$ \\
\hline Rendah & 17 & 11 & & \\
\hline Cukup & 5 & 6 & & \\
\hline
\end{tabular}

Pola hubungan faktor risiko perilaku dan lingkungan penderita AKK usia $\leq 40$ tahun dengan usia $>40$ tahun tidak terdapat perbedaan bermakna faktor-faktor risiko AKK diet tinggi lemak dan protein, rendah serat, alkohol, obesitas, merokok, dan aktivitas fisik yang rendah penderita AKK $\leq 40$ tahun dibandingkan dengan AKK $>40$ tahun (Tabel 2).

Hasil pemeriksaan imunohistokimia untuk status IM dan ekspresi P53 penderita AKK usia $\leq 40$ tahun dan usia $>40$ tahun, hasil uji statistik tidak terdapat perbedaan bermakna antara kedua kelompok tersebut, dengan nilai $\mathrm{p}=0,623$ (Tabel $3)$.
Perbandingan pola hubungan faktor risiko AKK berdasarkan status IM pada penderita AKK $\leq 40$ tahun dan $>40$ tahun menunjukkan perbedaan bermakna berdasarkan diet lemak antara status IM positif dan negatif $(p \leq 0,05)$. Meskipun demikian, tidak terdapat perbedaan bermakna faktor risiko AKK berdasarkan diet protein dan sayuran, serta alkoholisme, obesitas, aktivitas fisik rendah dan merokok (Tabel 4 dan 5).

Analisis pola hubungan faktor risiko AKK berdasarkan status ekspresi P53 pada penderita AKK usia $\leq 40$ tahun dan usia $>40$ tahun, tidak terdapat perbedaan bermakna pada faktor risiko AKK berdasarkan diet lemak antara status IM

Tabel 3 Perbandingan Status Instabilitas Mikrosatelit dan Ekspresi P53 antara Penderita AKK $\leq 40$ Tahun dan $>40$ Tahun

\begin{tabular}{lcccc}
\hline Variabel & $\begin{array}{c}\mathbf{4 4 0} \text { Tahun } \\
\mathbf{n = 2 2}\end{array}$ & $\begin{array}{c}>\mathbf{4 0} \text { Tahun } \\
\mathbf{n = 1 7}\end{array}$ & $\mathbf{p}$ & $\mathbf{R P}(\mathbf{9 5 \%} \mathbf{~ I K})$ \\
\hline Status instabilitas mikrosatelit & 5 & & 0,623 & $0,98(0,50-1,90)$ \\
$\quad$ Positif & 5 & 4 & & \\
$\quad$ Negatif & 17 & 13 & & \\
Ekspresi $P 53$ & & & 0,232 & $0,71(0,41-1,24)$ \\
$\quad$ Positif & 10 & 11 & & \\
$\quad$ Negatif & 12 & 6 & & \\
\hline
\end{tabular}

Keterangan: $\mathrm{RP}=$ risiko prevalens, $\mathrm{IK}=$ interval kepercayaan 
Tabel 4 Hubungan Faktor Risiko Perilaku dan Lingkungan dengan Status Instabilitas Mikrosatelit pada Penderita $A K K \leq 40$ Tahun

\begin{tabular}{|c|c|c|c|c|}
\hline \multirow{2}{*}{ Variabel } & \multicolumn{2}{|c|}{ Status Instabilitas Mikrosatelit } & \multirow{2}{*}{$\mathbf{p}$} & \multirow{2}{*}{ RP (95\%IK) } \\
\hline & $(+)$ & $(-)$ & & \\
\hline Diet lemak & & & 0,021 & $0,64(0,43-0,95)$ \\
\hline Tinggi & 5 & 9 & & \\
\hline Rendah & 0 & 8 & & \\
\hline Diet protein & & & 0,316 & $0,46(0,96-2,23)$ \\
\hline Tinggi & 2 & 11 & & \\
\hline Rendah & 3 & 6 & & \\
\hline Diet sayuran & & & 0,589 & $0,75(0,58-0,97)$ \\
\hline Rendah & 5 & 15 & & \\
\hline Tinggi & 0 & 2 & & \\
\hline Alkohol & & & 0,411 & $2,50(0,48-12,89)$ \\
\hline Positif & 1 & 1 & & \\
\hline Negatif & 4 & 16 & & \\
\hline Indeks massa tubuh & & & 0,580 & \\
\hline Underweight & 0 & 2 & & $0,98(0,50-1,90)$ \\
\hline Normal & 2 & 6 & & 1 \\
\hline Overweight & 3 & 9 & & $0,98(0,50-1,90)$ \\
\hline Merokok & & & 0,316 & $2,17(0,45-10,46)$ \\
\hline Ya & 3 & 6 & & \\
\hline Tidak & 2 & 11 & & \\
\hline Aktivitas fisik & & & 0,550 & $1,96(0,044-0,87)$ \\
\hline Rendah & 2 & 15 & & \\
\hline Cukup & 3 & 2 & & \\
\hline
\end{tabular}

positif dan negatif pada penderita AKK usia $>40$ tahun $(\mathrm{p}=0,026)$, demikian pula tidak terdapat perbedaan bermakna untuk faktor risiko AKK lainnya pada kelompok tersebut $(\mathrm{p}>0,05$; Tabel 6). Pola hubungan faktor risiko AKK dengan ekspresi mutasi gen $p 53$ pada penderita AKK usia $>40$ tahun tidak menunjukkan perbedaan bermakna $(\mathrm{p}>0,05)$.

\section{Pembahasan}

Frekuensi penderita AKK laki-laki sedikit lebih banyak dibandingkan dengan perempuan pada penelitian ini. Hal ini sesuai dengan estimasi WHO bahwa kejadian AKK berdasarkan jenis kelamin laki-laki sedikit lebih banyak daripada perempuan dengan perbandingan 19,4 dan 15,3 per 100.000 penduduk. ${ }^{2,4}$

Persentase penderita AKK usia $\leq 40$ tahun pada penelitian ini didapatkan $56,4 \%$, dengan demikian, membuktikan angka kejadian AKK usia $\leq 40$ tahun di Indonesia tinggi. Berdasarkan literatur dari Eropa dan Amerika, angka kejadian penderita AKK usia $\leq 40$ tahun lebih rendah jika dibandingkan dengan negara di Asia, yaitu $2-8 \%{ }^{8,9}$ Oleh karena itu, hasil penelitian ini mendukung penelitian-penelitian di Indonesia sebelumnya yaitu berkisar antara $15 \%$ dan $54 \% .^{10}$

Untuk lokasi tumor dan jenis histopatologi, tidak ada perbedaan bermakna antara kelompok usia AKK usia $\leq 40$ dan usia $>40$ tahun. Hal ini berbeda dengan literatur, karena pada AKK usia $\leq 40$ tahun lebih banyak ditemukan lokasi pada kolon kanan dengan jenis histopatologi terbanyak adenokarsinoma musinosa. ${ }^{12-14}$ Oleh karena itu, dapat disimpulkan bahwa lokasi dan jenis histopatologi AKK pada kelompok usia $\leq 40$ tahun pada orang Indonesia berbeda dengan Eropa dan Amerika, sehingga menimbulkan pertanyaan apakah jalur karsinogenesis berbeda pula? Untuk menjelaskan keadaan tersebut,dilakukan analisis membandingkan status IM dengan IK secara imunohistokimia pada kedua kelompok tersebut. Hasilnya pada penelitian tidak terdapat perbedaan bermakna dalam hal status IM antara penderita AKK usia $\leq 40$ tahun bila dibandingkan dengan usia $>40$ tahun. Demikian pula untuk ekspresi P53, ditemukan hasil yang sama antara kedua kelompok tersebut. Secara umum, pola hubungan genetik molekuler antara kelompok penelitian menunjukkan persamaan yaitu tingginya ekspresi $P 53$ yang berasosiasi dengan rendahnya proporsi status IM. Oleh karena itu, dapat disimpulkan faktor yang berperan ialah jalur karsinogenesis 
Tabel 5 Hubungan Faktor Risiko Perilaku dan Lingkungan AKK berdasarkan Status Instabilitas Mikrosatelit pada Penderita AKK >40 Tahun

\begin{tabular}{|c|c|c|c|c|}
\hline \multirow{2}{*}{ Variabel } & \multicolumn{2}{|c|}{ Status Instabilitas Mikrosatelit } & \multirow{2}{*}{$\mathbf{p}$} & \multirow{2}{*}{ RP (95\% IK) } \\
\hline & $(+)$ & $(-)$ & & \\
\hline Diet lemak & & & 0,026 & $5,14(0,79-33,51)$ \\
\hline Tinggi & 3 & 10 & & \\
\hline Rendah & 1 & 3 & & \\
\hline Diet protein & & & 0,330 & $2,40(0,46-12,6)$ \\
\hline Tinggi & 2 & 3 & & \\
\hline Rendah & 2 & 10 & & \\
\hline Diet sayuran & & & 0,765 & $0,75(0,56-0,99)$ \\
\hline Rendah & 4 & 12 & & \\
\hline Tinggi & 0 & 1 & & \\
\hline Alkohol & & & - & - \\
\hline Positif & 0 & 0 & & \\
\hline Negatif & 4 & 13 & & \\
\hline Indeks massa tubuh & & & 0,774 & \\
\hline Underweight & 1 & 4 & & $0,98(0,50-1,90)$ \\
\hline Normal & 1 & 5 & & 1 \\
\hline Overweight & 2 & 4 & & $0,98(0,50-1,90)$ \\
\hline Merokok & & & 0,665 & $0,89(0,16-4,93)$ \\
\hline Ya & 2 & 7 & & \\
\hline Tidak & 2 & 6 & & \\
\hline Aktivitas fisik & & & 0,139 & $0,63(0,40-0,99)$ \\
\hline Rendah & 4 & 7 & & \\
\hline Cukup & 0 & 6 & & \\
\hline
\end{tabular}

sporadik. Keadaan ini berbeda dengan literatur yang ada, pada kelompok AKK usia $\leq 40$ tahun didapatkan tingkat proporsi IM yang tinggi dan berasosiasi dengan rendahnya proporsi P53, sedangkan pada AKK usia $>40$ tahun berlaku sebaliknya. ${ }^{13}$

Dengan hasil penemuan ini, kami melakukan analisis lebih lanjut, yaitu meneliti kemungkinan hubungan berbagai faktor risiko AKK yang telah diketahui dengan jenis mutasi genetik molekulernya antara kedua kelompok. Sepanjang pengetahuan kami, belum pernah dipublikasi peran berbagai faktor risiko tersebut di Indonesia.

Berdasarkan faktor risiko riwayat adenoma/ karsinoma, pada penelitian ini ditemukan 3 orang penderita dengan riwayat AKK sebelumnya, yaitu 1 orang penderita berusia 53 tahun dan P53 positif, dan 2 orang masing-masing berusia 40 tahun dan 36 tahun dengan IM dan P53 negatif. Dapat disimpulkan bahwa faktor risiko riwayat adenoma/karsinoma hanya terdapat pada satu orang penderita yaitu pada penderita dengan riwayat AKK dengan P53 positif pada usia 53 tahun. Pada dua orang lainnya, kemungkinan mutasi gen terkait dengan tipe wild type atau gen $M M R$ lainnya yang tidak terdeteksi pada pemeriksaan imunohistokimia. ${ }^{14} \mathrm{Hal}$ ini dapat pula terjadi pada gen $M M R$ lainnya yaitu, $P M S 1$, PMS2, MSH3, dan MSH6 yang tidak diperlukan pada penelitian ini. ${ }^{13}$ Meskipun demikian, gen tersebut hanya berperan pada presentasi yang rendah bila dibandingkan dengan gen $M L H I$ dan MSH2.

Untuk faktor risiko riwayat IBD, diperoleh 5 orang penderita dan telah diderita $<5$ tahun. Kondisi ini akan meningkatkan kejadian AKK hingga $10-29 \%$ bila telah diderita $>10$ tahun. ${ }^{15}$ Oleh karena itu, pada penelitian ini faktor risiko tersebut tidak berperan di dalam karsinogenesis AKK pada penderita, sedangkan faktor riwayat kolesistektomi tidak berperan pada penelitian ini, karena tidak ditemukan satu pun penderita yang memiliki riwayat tersebut.

Pada penelitian ditemukan 3 orang penderita dengan riwayat $\mathrm{AKK}$ dalam keluarga yaitu riwayat AKK pada 2 orang dan 1 orang dengan riwayat AKK dan karsinoma payudara. Kedua penderita tersebut menunjukkan status $P 53$ positif dan IM negatif, serta terjadi pada usia $>40$ tahun. Dapat disimpulkan ketiga penderita tersebut merupakan AKK familial, bukan herediter, sedangkan pada kelompok AKK usia $\leq 40$ tahun tidak ditemukan dengan riwayat keluarga. Hal ini berbeda dengan di negara Eropa dan Amerika bahwa penderita 
Tabel 6 Hubungan Faktor Risiko Perilaku Dan Lingkungan AKK berdasarkan Status Ekspresi $P 53$ pada Penderita AKK $\leq 40$ Tahun dan AKK $>40$ Tahun

\begin{tabular}{|c|c|c|c|c|}
\hline \multirow{2}{*}{ Variabel } & \multicolumn{2}{|c|}{ Ekspresi P53 } & \multirow{2}{*}{$\mathbf{p}$} & \multirow{2}{*}{ RP (95\%IK) } \\
\hline & $(+)$ & $(-)$ & & \\
\hline \multicolumn{5}{|c|}{ Penderita AKK $\leq \mathbf{4 0}$ Tahun } \\
\hline Diet lemak & & & 0,700 & $0,92(0,12-6,59)$ \\
\hline Tinggi & 9 & 5 & & \\
\hline Rendah & 1 & 7 & & \\
\hline Diet protein & & & 0,639 & $1,03(0,40-2,65)$ \\
\hline Tinggi & 6 & 7 & & \\
\hline Rendah & 4 & 5 & & \\
\hline Diet sayuran & & & 0,714 & $0,90(0,20-3,90)$ \\
\hline Rendah & 9 & 11 & & \\
\hline Tinggi & 1 & 1 & & \\
\hline Alkohol & & & 0,195 & $2,50(1,46-4,27)$ \\
\hline Positif & 2 & 0 & & \\
\hline Negatif & 8 & 12 & & \\
\hline Indeks massa tubuh & & & 0,926 & \\
\hline Underweight & 1 & 1 & & $0,98(0,50-1,90)$ \\
\hline Normal & 4 & 4 & & 1 \\
\hline Overweight & 5 & 7 & & $0,98(0,50-1,90)$ \\
\hline Merokok & & & 0,305 & $0,62(0,22-1,78)$ \\
\hline Ya & 3 & 6 & & \\
\hline Tidak & 7 & 6 & & \\
\hline Aktivitas fisik & & & 0,594 & $1,18(0,36-3,85)$ \\
\hline Rendah & 8 & 9 & & \\
\hline Cukup & 2 & 3 & & \\
\hline \multicolumn{5}{|c|}{ Penderita AKK >40 Tahun } \\
\hline Diet lemak & & & 0,026 & $5,14(0,79-33,51)$ \\
\hline Tinggi & 3 & 10 & & \\
\hline Rendah & 1 & 3 & & \\
\hline Diet protein & & & 0,330 & $2,40(0,46-12,6)$ \\
\hline Tinggi & 2 & 3 & & \\
\hline Rendah & 2 & 10 & & \\
\hline Diet sayuran & & & 0,765 & $0,75(0,56-0,99)$ \\
\hline Rendah & 4 & 12 & & \\
\hline Tinggi & 0 & 1 & & \\
\hline Alkohol & & & - & - \\
\hline Positif & 0 & 0 & & \\
\hline Negatif & 4 & 13 & & \\
\hline Indeks massa tubuh & & & 0,774 & \\
\hline Underweight & 1 & 4 & & $0,98(0,50-1,90)$ \\
\hline Normal & 1 & 5 & & 1 \\
\hline Overweight & 2 & 4 & & $0,98(0,50-1,90)$ \\
\hline Merokok & & & 0,665 & $0,89(0,16-4,93)$ \\
\hline $\mathrm{Ya}$ & 2 & 7 & & \\
\hline Tidak & 2 & 6 & & \\
\hline Aktivitas fisik & & & 0,139 & $0,63(0,40-0,99)$ \\
\hline Rendah & 4 & 7 & & \\
\hline
\end{tabular}

Keterangan: $\mathrm{RP}=$ risiko prevalens, $\mathrm{IK}=$ interval kepercayaan 
AKK usia $\leq 40$ tahun mayoritas penderita AKK herediter dalam bentuk HNPCC dan FAP yang diagnosisnya ditegakkan bedasarkan dua kriteria yaitu Amsterdam dan Bethesda. ${ }^{8}$

Walaupun antara kedua kelompok usia tidak terdapat perbedaan faktor risiko yang bermakna, pada keduanya dapat disimpulkan beberapa faktor risiko perilaku dan lingkungan yang berperan. Untuk kelompok AKK usia $\leq 40$ tahun yaitu pola diet tinggi lemak, tinggi protein, rendah serat, overweight, dan aktivitas fisik rendah. Pada AKK usia $>40$ tahun yang berperan yaitu diet tinggi lemak, rendah serat, merokok, dan aktivitas fisik rendah. Hal ini sesuai dengan teori bahwa diet tinggi lemak dan daging merah meningkatkan faktor risiko untuk terjadi AKK sebanyak $20 \%{ }^{15}$ Overweight, merokok, dan aktivitas fisik rendah, masing-masing mempunyai risiko relatif 1,84 ; 1,32; dan 4 kali.Secara khusus untuk diet tinggi lemak, ternyata berperan dan berbeda bermakna pada kelompok AKK usia $\leq 40$ tahun antara yang berstatus IM positif dan negatif. Diet tinggi lemak ditemukan lebih banyak pada penderita dengan status IM negatif dan ini berarti bahwa mayoritas pada kelompok ini faktor risiko yang berperan yaitu faktor diet tinggi lemak, bukan akibat faktor genetik herediter. Tentunya hal ini berbeda pula dengan yang ditemui di negara Amerika Utara dan Eropa, karena faktor risiko yang paling berperan faktor genetik herediter. ${ }^{9}$

Simpulan, penderita AKK kelompok usia $\leq 40$ tahun dan usia $>40$ tahun pada orang Indonesia memiliki pola hubungan genetik molekuler yang tidak berbeda, yaitu terdapat proporsi status IK yang tinggi dan proporsi status IM rendah, serta keduanya berhubungan dengan faktor risiko diet tinggi lemak dan protein, rendah serat, overweight, merokok, dan dengan aktivitas fisik rendah. Oleh karena itu, kedua kelompok AKK tersebut berada pada jalur karsinogenesis sporadik. Diharapkan dengan mengetahui faktor-faktor risiko tersebut, sekiranya dapat menjadi landasan untuk program pencegahan AKK dan metode skrining pada kelompok AKK usia $<40$ tahun di Indonesia.

\section{Daftar Pustaka}

1. Jemal A, Center MM, DeSantis C, Ward EM. Global patterns of cancer incidence and mortality rates and trends. Cancer Epidemiol Biomarkers Prev. 2010;19(8):1893-907.

2. Ferlay J, Shin HR, Bray F, Forman D, Mathers
C, Parkin DM. Estimates of worldwide burden of cancer in 2008: GLOBOCAN 2008. Int J Cancer. 2010;127(12):2893-917.

3. Jemal A, Bray F, Center MM, Ferlay J, Ward E, Forman D. Global cancer statistics. CA Cancer J Clin. 2011;61(2):69-90.

4. Ferlay J, Bray F, Pisani P, Parkin DM. GLOBOCAN 2002: Cancer incidence, mortality and prevalence. Worldwide IARC Cancer Base, vol 5, version 2.0. Lyon: IARC Press, 2004.

5. American Cancer Society. Cancer Facts \& Figures, 2002. New York: American Cancer Society Inc. Surveillance Research $2002 ; 02-$ 250M No 508.02:20-6.

6. National Cancer Institute. Rectal Cancer[online website homepage] 2004 [diunduh 27 Maret 2008]. Tersedia dari: www.cancer.gov.

7. O'Connell JB, Maggard MA, Livingston EH, Yo CK. Colorectal cancer in the young.Am J Surg. 2004;187(3):343-8.

8. Church JM, Casey G. Molecular genetics and colorectal neoplasia. A primer for the clinician. Edisi ke-2. Boston: Kluwer Academic Publishers; 2004.

9. Lin JT, Wang WS, Yen CC, Liu JH, Yang $\mathrm{MH}$, Chao TC, dkk. Outcome of colorectal carcinoma in patients under 40 years of age. J Gastroenterol Hepatol. 2005;20(6):900-5.

10. Riwanto I. Skrining dan surveilans karsinoma kolo-rektal. Perpaduan antara risiko kejadian penyakit terhadap biaya yang diperlukan. Proceeding of First IKABDI Colorectal Week, 2002.

11. Markowitz SD, Bertagnolli MM. Molecular origins of cancer:molecular basis of colorectar cancer. N Engl J Med. 2009;361(25):2449-60.

12. Boland CR, Goel A. Microsatellite instability in colorectal cancer. Gastroenterology. 2010; 138(6):2073-87.

13. Ogino S, Goel A. Molecular classification and correlates in colorectal cancer. J Mol Diagn. 2008;10(1):13-27.

14. Moran A, Ortega P, de Juan C, FernándezMarcelo T, Frías C, Sánchez-Pernaute A, dkk. Differential colorectal carcinogenesis: molecular basis and clinical relevance. World J Gastrointest Oncol. 2010;2(3):151-8.

15. Chen K, Qiu JL, Zhang Y, Zhao YW. Meta analysis of risk factors for colorectal cancer. World J Gastroenterol. 2003;9(7):1598-1600. 